\title{
Algoritma Genetika untuk Optimasi Komposisi Makanan Bagi Penderita Hipertensi
}

\author{
Genetic Algorithm for Optimizing Food Composition for Hypertension Patients
}

\author{
Anggi Mahadika Purnomo, Davia Werdiastu, Talitha Raissa, Restu Widodo, Vivi Nur Wijayaningrum* \\ Fakultas Ilmu Komputer, Universitas Brawijaya \\ Jl. Veteran 8, Malang, Jawa Timur, Indonesia 65145
}

Cara sitasi: A. M. Purnomo, D. Werdiastu, T. Raissa, R. Widodo, and V. N. Wijayaningrum, "Algoritma Genetika untuk Optimasi Komposisi Makanan Bagi Penderita Hipertensi," Jurnal Teknologi dan Sistem Komputer, vol. 7, no. 1, 2019. doi: 10.14710/jtsiskom.7.1.2019.1-6, [Online].

\begin{abstract}
Hypertension can be prevented and handled by eating nutritious foods with the right composition. The genetic algorithm can be used to optimize the food composition for people with hypertension. Data used include sex, age, weight, height, activity type, stress level, and patient hypertension level. This study uses a reproduction method that is good enough to be applied to integer chromosome representations so that the search results provided are not local optimum solutions. The testing results show that the best genetic algorithm parameters are as follows population size is 15 with average fitness 20.97 , the generation number is 40 with average fitness 50.10 , and combination crossover rate and mutation rate are 0.3 and 0.7 with average fitness 41.67. The solution obtained is the optimal food composition for people with hypertension.
\end{abstract}

Keywords - genetic algorithm; hypertension; food composition; stroke; high blood pressure

\begin{abstract}
Abstrak - Hipertensi dapat dicegah dan ditangani dengan mengonsumsi makanan bergizi dengan komposisi yang tepat. Algoritma genetika dapat digunakan untuk mengoptimalkan komposisi makanan bagi penderita hipertensi. Data yang digunakan meliputi jenis kelamin, umur, berat badan, tinggi badan, jenis aktivitas, tingkat stres, dan tingkat hipertensi pasien. Penelitian ini menggunakan metode reproduksi yang cukup baik untuk diterapkan pada representasi kromosom integer sehingga hasil pencarian yang diberikan terhindar dari solusi optimum lokal. Hasil pengujian menunjukkan bahwa parameter algoritma genetika terbaik adalah populasi sebanyak 15 dengan rata-rata fitness sebesar 20,97, generasi sebanyak 40 dengan rata-rata fitness sebesar 50,10, dan kombinasi crossover rate dan mutation rate sebesar 0,3 dan 0,7 dengan rata-rata fitness sebesar 41,67. Solusi yang dihasilkan adalah berupa komposisi makanan optimal bagi penderita hipertensi.
\end{abstract}

*) Penulis korespondensi (Vivi Nur Wijayaningrum) Email: vivinurw@gmail.com
Kata Kunci - algoritma genetika; hipertensi; komposisi makanan; stroke; tekanan darah tinggi

\section{Pendahuluan}

Keadaan dimana sejumlah darah dipompakan oleh jantung melebihi kemampuan yang dapat ditampung dinding arteri sehingga terjadi peningkatan tekanan darah sistole lebih dari $140 \mathrm{mmHg}$ dan tekanan darah diastole lebih dari $90 \mathrm{mmHg}$ sering disebut dengan hipertensi atau tekanan darah tinggi [1]. Banyak penyakit tidak menular yang muncul akibat penyakit hipertensi, contohnya penyakit jantung dan stroke. Penyakit hipertensi dapat membunuh orang secara diam-diam karena gejala yang dialami oleh setiap individu hampir sama dengan gejala-gejala penyakit pada umumnya, seperti mimisan, sakit kepala di tengkuk, jantung berdebar-debar, dan penglihatan kabur.

Hipertensi menjadi salah satu masalah utama pada kesehatan masyarakat. Pada tahun 2025, kasus hipertensi diperkirakan akan meningkat sebesar 80\% dari jumlah total 639 juta kasus pada tahun 2000 [2]. Salah satu penyebab meningkatnya hipertensi adalah gaya hidup masyarakat yang cenderung tidak sehat. Gaya hidup ini meliputi faktor makanan, merokok, aktivitas fisik, dan stres [3]. Gaya hidup sehat bagi penderita hipertensi sangat perlu dilakukan sejak mereka mendapat diagnosa menderita penyakit tersebut.

Permasalahan penentuan komposisi makanan dapat diselesaikan menggunakan berbagai metode, salah satunya adalah Linear Programming. Linear Programming telah digunakan dalam [4] untuk merancang pola asupan makanan optimal bagi orang dewasa dengan meminimalkan selisih asupan makanan antara pola asupan makanan yang diamati dengan pola asupan makanan yang dioptimalkan sehingga memenuhi kebutuhan nutrisi. Penelitian tersebut menggunakan data yang terdiri dari 92 orang wanita berumur 31-69 tahun dan 82 orang pria berumur 32-69 tahun yang berada di Jepang. Sebanyak 1299 jenis makanan tercatat sebagai menu makanan diet.

Pada penelitian yang lain, pendekatan Linear Programming digunakan untuk memodelkan diet 
DASH (Dietary Approach to Stop Hypertension) yang optimal bagi penderita hipertensi [5]. Linear Programming digunakan untuk menentukan komposisi makanan dengan biaya paling sedikit untuk memenuhi kebutuhan nutrisi seorang penderita hipertensi. Pada diet DASH, beberapa nutrisi yang diminimalkan adalah natrium, lemak, dan kolesterol, sedangkan nutrisi yang harus dimaksimalkan adalah magnesium, kalium, kalsium, fiber, dan kalori untuk mengurangi tekanan darah tinggi. Formulasi disusun berdasarkan batasanbatasan nutrisi yang sudah ditentukan tersebut. Hasil akhir yang diberikan berupa ukuran porsi harian untuk setiap makanan dalam satu hari.

Walaupun telah banyak diterapkan dalam penentuan komposisi makanan, Linear Programming dapat menghasilkan solusi yang tidak layak jika diterapkan pada masalah multiobjektif yang ada dalam penentuan komposisi makanan [6]. Selain itu Linear Programming mempunyai keterbatasan ketika fungsi objektif dan fungsi kendala linier dalam variabel yang tidak diketahui [7].

Di sisi lain, algoritma genetika sebagai salah satu algoritma metaheuristik mampu menyelesaikan permasalahan multi objektif seperti formulasi pakan unggas [8], [9] dan distribusi barang farmasi [10]. Algoritma genetika telah digunakan untuk menentukan komposisi makanan penderita hipertensi menggunakan one-cut-point crossover [11]. Namun, metode crossover tersebut dianggap tidak dapat memberikan kombinasi yang baik dari kromosom induk [12], [13].

Pada penelitian ini, algoritma genetika digunakan untuk menyusun komposisi makanan bagi penderita hipertensi dengan menggunakan metode crossover yang cukup baik, yaitu extended intermediate crossover. Metode ini diharapkan mampu menghasilkan kromosom offspring yang lebih beragam, namun tetap mirip dengan kromosom induknya. Data yang digunakan meliputi data penderita hipertensi dan data makanan. Data penderita terdiri dari umur, berat badan, tinggi badan, jenis kelamin, jenis pekerjaan, dan tekanan darah yang digunakan sebagai penentu kebutuhan nutrisi harian setiap individu. Data makanan terdiri dari jenis makanan, berat makanan, total energi, karbohidrat, protein, lemak, natrium, dan kalium. Algoritma genetika diharapkan dapat menghasilkan komposisi menu makanan yang tepat bagi para penderita hipertensi.

\section{Metode Penelitian}

Penelitian ini menggunakan data pasien penderita hipertensi yang terdiri dari jenis kelamin, umur, berat badan, tinggi badan, jenis aktivitas, tingkat stres, dan tekanan darah. Data makanan yang digunakan terdiri dari 12 jenis makanan pokok, 20 jenis makanan sumber nabati, 32 jenis makanan sumber hewani, 31 jenis sayuran, dan 95 jenis makanan pelengkap. Setiap jenis makanan mempunyai rincian nilai kandungan energi, karbohidrat, protein, lemak, natrium, dan kalium.
Tabel 1. Klasifikasi IMT di Indonesia [14]

\begin{tabular}{|c|c|c|}
\hline IMT & Kategori & Keterangan \\
\hline$<17.0$ & Kurus & $\begin{array}{l}\text { Kekurangan berat badan } \\
\text { tingkat berat }\end{array}$ \\
\hline $17.0-18.4$ & Kurus & $\begin{array}{l}\text { Kekurangan berat badan } \\
\text { tingkat ringan }\end{array}$ \\
\hline $18.5-25.0$ & Normal & Berat badan normal \\
\hline $25.1-27.0$ & Gemuk & $\begin{array}{l}\text { Kelebihan berat badan } \\
\text { tingkat ringan }\end{array}$ \\
\hline$>27.0$ & Gemuk & $\begin{array}{l}\text { Kelebihan berat badan } \\
\text { tingkat berat }\end{array}$ \\
\hline
\end{tabular}

\section{A. Tahapan Penyusunan Komposisi Makanan}

Penyusunan komposisi makanan didasarkan pada kebutuhan energi dan zat gizi setiap individu yang dilakukan dengan langkah-langkah sebagai berikut:

1. Menghitung Indeks Massa Tubuh (IMT) dan Berat Badan Ideal (BBI)

Perhitungan IMT dan BBI dilakukan menggunakan Persamaan 1 dan Persamaan 2 dimana BB adalah berat badan dalam $\mathrm{kg}$ dan TB adalah tinggi badan dalam $\mathrm{m}$. IMT digunakan untuk memperkirakan massa tubuh seseorang, termasuk lemak di dalamnya. Tabel 1 menunjukkan klasifikasi IMT di Indonesia [14].

$$
\begin{gathered}
I M T=\frac{B B}{T B^{2}} \\
B B I=(T B-100)-10 \%(T B-100)
\end{gathered}
$$

\section{Menghitung Basal Metabolic Rate (BMR)}

BMR menunjukkan energi yang dibutuhkan untuk menjaga fungsi normal tubuh pada kondisi istirahat [15]. BMR dapat dihitung dengan menggunakan rumus Harris Benedict [16], yaitu untuk penderita laki-laki menggunakan Persamaan 3a, sedangkan penderita perempuan menggunakan Persamaan 3b. untuk penderita perempuan. BB menyatakan berat badan dalam kg, TB adalah tinggi badan dalam cm, dan umur dalam tahun.

$$
\begin{gathered}
B M R=66+(13,7 \times B B)+(5 \times T B)-(6.8 \times \text { umur }) \\
B M R=65,5+(9,6 \times B B)+(1,7 \times T B)+(4,7 \times \text { umur })
\end{gathered}
$$

\section{Menghitung Kebutuhan Energi (KE)}

Kebutuhan energi dapat diperkirakan dari jumlah energi yang dibutuhkan dan pengeluaran energi untuk aktivitas fisik. Kebutuhan energi dapat dihitung dengan menggunakan Persamaan 4.

$$
K E=B M R \times \text { faktor aktivitas } \times \text { faktor stres }
$$

Aktivitas fisik dikelompokkan menjadi ringan, sedang, dan berat dengan nilai faktor aktivitas yang berbeda-beda sesuai dengan jenis kelamin. Nilai faktor aktivitas dinyatakan dalam Tabel 2. Aktivitas ringan menunjukkan bahwa 75\% aktivitas dilakukan dengan duduk atau berdiri dan $25 \%$ bergerak atau berdiri. Aktivitas sedang menunjukkan bahwa 25\% aktivitas 
Tabel 2. Nilai faktor aktivitas sesuai jenis kelamin [15]

\begin{tabular}{ccc}
\hline Aktivitas & Laki-laki & Perempuan \\
\hline Ringan & 1,56 & 1,55 \\
Sedang & 1,76 & 1,70 \\
Berat & 2,10 & 2,00 \\
\hline
\end{tabular}

dilakukan dengan duduk atau berdiri dan 75\% aktivitas pekerjaan. Aktivitas berat menunjukkan bahwa aktivitas dilakukan dengan duduk atau berdiri dan 60\% aktivitas pekerjaan.

Tingkat stres terbagi menjadi tiga, yaitu stres ringan, stres sedang, dan stres berat. Stres ringan mempunyai nilai faktor stres 1,3 , stres sedang bernilai 1,5 , dan stres berat bernilai 2,0 [16].

\section{Menghitung kebutuhan zat gizi}

Zat gizi atau nutrisi diperoleh dari makanan dan digunakan untuk pertumbuhan, pemeliharaan, dan perbaikan jaringan tubuh [17]. Perhitungan kebutuhan zat gizi karbohidrat, protein, dan lemak dilakukan dengan menggunakan Persamaan 5, Persamaan 6, dan Persamaan 7. Berdasarkan tabel Angka Kebutuhan Gizi (AKG) 2013, angka kecukupan natrium setiap orang perhari adalah $1500 \mathrm{mg}$ dan angka kecukupan kalium yang dianjurkan adalah $4700 \mathrm{mg}$ perhari.

$$
\begin{gathered}
\text { Karbohidrat }=\frac{65 \% \times K E}{4} \\
\text { Protein }=\frac{15 \% \times K E}{4} \\
\text { Lemak }=\frac{20 \% \times K E}{9}
\end{gathered}
$$

\section{B. Representasi Kromosom}

Representasi kromosom yang digunakan adalah bilangan integer yang berisi nomor urutan dari setiap makanan. Sebuah kromosom terdiri dari 14 gen yang berisi nilai indeks makanan. Lima gen pertama menggambarkan komposisi makanan untuk makan pagi, lima gen kedua untuk makan siang, dan empat gen terakhir untuk makan malam.

Contoh kromosom yang dibentuk ditunjukkan pada Gambar 1. Kromosom tersebut terdiri dari makanan pokok, sumber nabati, sumber hewani, sayuran, dan makanan pelengkap dengan rincian sebagai berikut:

- Makanan pokok direpresentasikan pada gen ke-1, gen ke-6, dan gen ke-11

- Makanan sumber nabati direpresentasikan pada gen ke-2, gen ke-7, dan gen ke-12

- Makanan sumber hewani direpresentasikan pada gen ke-3, gen ke-8, dan gen ke-13

- Sayuran direpresentasikan pada gen ke-4, gen ke9, dan gen ke-14

- Makanan pelengkap direpresentasikan pada gen ke-5 dan gen ke-10

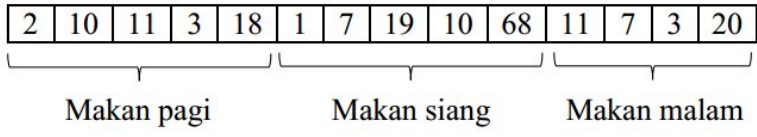

Gambar 1. Contoh kromosom

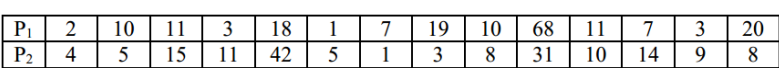

\begin{tabular}{|c|c|c|c|c|c|c|c|c|c|c|c|c|c|c|}
\hline$\alpha$ & 0.71 & 0.14 & 0.25 & 0.87 & 0.10 & 0.65 & 0.02 & 0.13 & 0.03 & 0.22 & 0.14 & 0.31 & 0.03 & 0.08 \\
\hline
\end{tabular}

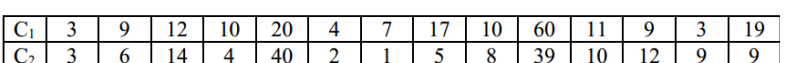

Gambar 2. Contoh representasi proses crossover

\begin{tabular}{|l|l|l|l|l|l|l|l|l|l|l|l|l|l|l}
\hline $\mathrm{P}$ & 5 & 16 & 28 & 7 & 70 & 3 & 18 & 26 & 23 & 66 & 3 & 16 & 22 & 11 \\
\hline
\end{tabular}

\begin{tabular}{l|l|l|l|l|l|l|l|l|l|l|l|l|l|l}
$\mathrm{C}$ & 5 & 16 & 22 & 7 & 70 & 3 & 18 & 26 & 23 & 66 & 3 & 16 & 28 & 11 \\
\hline
\end{tabular}

Gambar 3. Contoh representasi proses mutasi

\section{Reproduksi}

Reproduksi digunakan untuk menghasilkan offspring dari induk yang sudah direpresentasikan. Reproduksi terdiri dari proses crossover dan mutasi. Proses crossover dilakukan dengan menggunakan extended intermediate crossover [12]. Proses ini dilakukan dengan cara memilih dua kromosom induk secara acak dan menentukan nilai $\alpha$ secara acak pada interval -0,25 sampai dengan 1,25. Dua buah offspring yang dihasilkan dari proses crossover didapatkan melalui perhitungan menggunakan Persamaan 8 dan Persamaan 9.

$$
\begin{gathered}
\text { Offspring }_{1}=\text { Induk }_{1}+\alpha\left(\text { Induk }_{2}-\text { Induk }_{1}\right) \\
\text { Offspring }_{2}=\text { Induk }_{2}+\alpha\left(\text { Induk }_{1}-\text { Indu }_{2}\right)
\end{gathered}
$$

Contoh proses crossover menggunakan extended intermediate crossover ditunjukkan pada Gambar 2. $\mathrm{P}_{1}$ dan $\mathrm{P}_{2}$ merupakan kromosom induk yang akan digunakan untuk proses crossover, $\alpha$ adalah nilai acak yang dibentuk untuk menghasilkan offspring, sedangkan $\mathrm{C}_{1}$ dan $\mathrm{C}_{2}$ merupakan kromosom offspring hasil dari proses crossover.

Proses mutasi dilakukan dengan menggunakan reciprocal exchange mutation, yaitu memilih satu induk kromosom yang akan dimutasi dan memilih dua posisi secara acak dari kromosom tersebut. Nilai gen yang terdapat pada kedua posisi tersebut selanjutnya ditukar sehingga menghasilkan satu buah offspring baru. Contoh proses mutasi ditunjukkan pada Gambar 3. P merupakan kromosom induk yang akan digunakan untuk proses mutasi dan C merupakan kromosom offspring hasil dari proses mutasi.

\section{Fungsi Fitness}

Fungsi fitness didapatkan dari hasil perhitungan total penalti yang berasal dari penalti kalori, karbohidrat, protein, lemak, natrium, dan kalium (Persamaan 10). Penalti digunakan pada masalah yang mempunyai 
batasan sehingga perlu dilakukan pengurangan nilai fitness pada solusi yang melanggar batasan yang sudah ditentukan [18]. Nilai penalti diberikan ketika terdapat zat gizi yang tidak memenuhi jumlah kebutuhan [19]. Penalti dihitung dari selisih kebutuhan zat gizi seorang pasien dengan total zat gizi yang diberikan setelah menu makanan tersusun.

$$
\text { Fitness }=\frac{10000}{1+\text { total penalti }}
$$

\section{E. Seleksi}

Proses seleksi dilakukan dengan menggunakan metode elitism selection, yaitu mengurutkan kromosom yang memiliki nilai fitness terbesar sampai dengan yang terkecil, kemudian memilih kromosom dengan nilai fitness teratas sejumlah ukuran populasi untuk dijadikan sebagai individu-individu pada generasi berikutnya.

\section{Hasil dan Pembahasan}

Berikut ini adalah contoh perhitungan kebutuhan energi yang dibutuhkan oleh seorang pasien penderita hipertensi menggunakan algoritma genetika. Perhitungan dilakukan terhadap seorang pasien dengan data sebagai berikut:

- Jenis kelamin : laki-laki

- Umur :50 tahun

- Berat badan : $62 \mathrm{~kg}$

- Tinggi badan : $165 \mathrm{~cm}$

- Jenis aktivitas : sedang

- Tingkat stres : ringan

- Tekanan darah : $170 \mathrm{mmHg}$

Berdasarkan data pasien tersebut, langkah pertama yang dilakukan adalah menghitung IMT dan BBI dengan menggunakan Persamaan 1 dan Persamaan 2. IMT pasien bernilai 22,7732 dan BBI bernilai 57,5 kg dengan perhitungan sebagai berikut:

$$
I M T=\frac{62}{1,65^{2}}=22,7732
$$

$$
B B I=(165-100)-10 \%(165-100)=57,5 \mathrm{~kg}
$$

Nilai BMR dihitung dengan menggunakan Persamaan 3a (untuk laki-laki). Kebutuhan energi atau kalori dengan menggunakan Persamaan 4 dan kebutuhan zat gizi menggunakan Persamaan 5 sampai Persamaan 7. Kebutuhan harian pasien untuk kecukupan natrium tetap sebesar $1500 \mathrm{mg}$ dan kalium sebesar 4700 mg. Perhitungan BMR, kebutuhan energi dan zat gizi pasien adalah sebagai berikut:

$$
\begin{gathered}
B M R=66+(13,7 \times 62)+(5 \times 165)-(6,8 \times 50)=1400,4 \\
K E=1400,4 \times 1,76 \times 1,3=3204,12 \\
\text { Karbohidrat }=\frac{65 \% \times 3204,12}{4}=520,67
\end{gathered}
$$

$$
\begin{gathered}
\text { Protein }=\frac{15 \% \times 3204,12}{4}=120,15 \\
\text { Lemak }=\frac{20 \% \times 3204,12}{9}=71,20
\end{gathered}
$$

\section{A. Perhitungan Nilai Fitness}

Perhitungan setiap zat gizi yang terkandung pada komposisi menu makanan yang telah dibentuk pada Gambar 1 dilakukan untuk mengetahui total zat gizi yang diberikan oleh menu makanan tersebut. Berdasarkan kromosom pada Gambar 1, menu makanan yang diberikan kepada pasien adalah sebagai berikut:

- Menu makan pagi: nasi jagung, sup kacang hijau, sup daging, sayur bayam dan jagung, dan jambu merah

- Menu makan siang: nasi goreng, semur tahu, telur puyuh, sayur jantung pisang, dan kue nagasari

- Menu makan malam: ketupat, semur tahu, semur daging ayam, dan tumis pucuk labu

Berdasarkan hasil perhitungan total zat gizi yang terkandung pada menu makanan tersebut, kandungan kalori yang diberikan sebesar 1844,6 kal, karbohidrat sebesar 193,91 gram, protein sebesar 82,8 gram, lemak sebesar 106,32 gram, natrium sebesar 265,2 mg, dan kalium sebesar 2218,6 mg. Dengan demikian, nilai penalti untuk setiap zat gizi didapatkan dengan menghitung selisih kebutuhan zat gizi pasien dan total ketersediaan zat gizi dari menu makanan sebagai berikut:

- $\quad$ Penalti kalori =3204,12-1844,6=1359,52

- $\quad$ Penalti karbohidrat $=520,67-193,91=326,76$

- $\quad$ Penalti protein $=120,15-82,8=37,35$

- $\quad$ Penalti lemak $=80,71-106,32=0$

- $\quad$ Penalti natrium $1500-265,2=1234,8$

- $\quad$ Penalti kalium $=4700-2218,6=2481,4$

Penalti lemak bernilai 0 karena zat gizi yang diberikan oleh makan bernilai lebih besar dibandingkan dengan kebutuhan zat gizi pasien tersebut, yang artinya kebutuhan lemak sudah terpenuhi. Total penalti dari keenam zat gizi tersebut adalah 5439,83. Nilai fitness dapat dihitung dengan menggunakan Persamaan 10 sebagai berikut:

$$
\text { Fitness }=\frac{10000}{1+5439,83}=1,84
$$

\section{B. Pengujian Ukuran Populasi}

Pengujian ukuran populasi dilakukan sebanyak 5 kali percobaan pada setiap skenario pengujian dengan rincian skenario ukuran populasi yaitu 3, 6, 9, 12, dan 15. Pengujian dilakukan menggunakan crossover rate 0,7 , mutation rate 0,3 , dan banyaknya generasi sebanyak 10. Hasil pengujian ukuran populasi ditunjukkan pada Gambar 4.

Berdasarkan grafik hasil pengujian ukuran populasi pada Gambar 4, ukuran populasi sebanyak 3 menghasilkan rata-rata nilai fitness sebesar 17,33, 


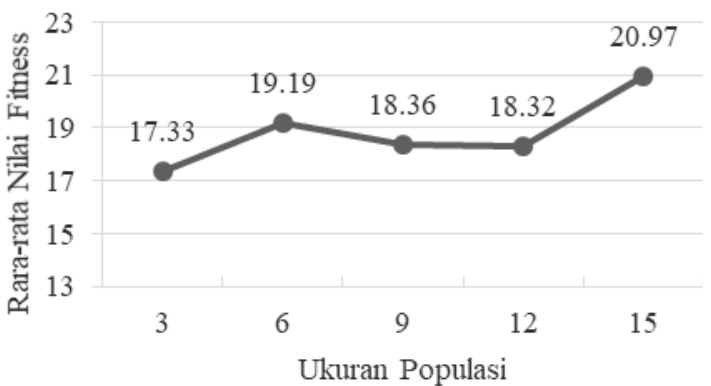

Gambar 4. Hasil pengujian ukuran populasi optimal

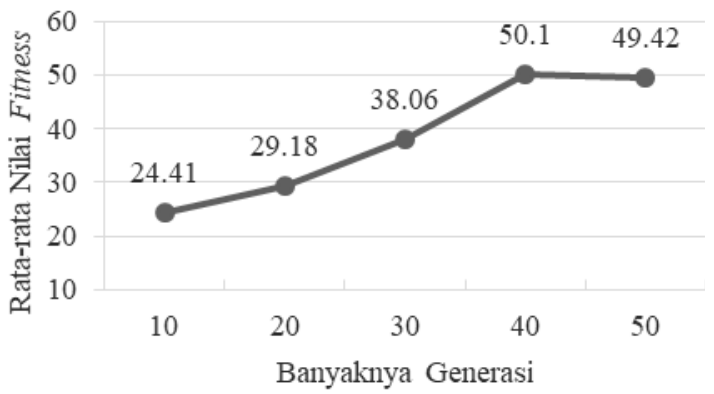

Gambar 5. Hasil pengujian banyaknya generasi optimal

kemudian mengalami peningkatan pada ukuran populasi sebanyak 6 dengan rata-rata nilai fitness sebesar 19,19. Rata-rata nilai fitness yang dihasilkan oleh ukuran populasi 6 sampai dengan 12 cenderung stabil, kemudian mengalami peningkatan kembali pada ukuran populasi sebanyak 15. Hal ini membuktikan bahwa penambahan ukuran populasi menjadikan algoritma genetika melakukan pencarian lebih luas sehingga bisa mendapatkan hasil yang lebih baik. Namun, penambahan jumlah populasi juga akan menambah waktu komputasi yang diperlukan. Berdasarkan hasil pengujian ukuran populasi tersebut, didapatkan ukuran populasi yang optimal adalah sebanyak 15 .

\section{Pengujian Banyaknya Generasi}

Pengujian banyaknya generasi dilakukan sebanyak 5 kali percobaan pada setiap skenario pengujian dengan rincian skenario banyaknya generasi yaitu 10, 20, 30, 40, dan 50. Pengujian dilakukan menggunakan crossover rate 0,7 , mutation rate 0,3 , dan ukuran populasi sebanyak 15 . Hasil pengujian banyaknya generasi ditunjukkan pada Gambar 5.

Berdasarkan grafik hasil pengujian banyaknya generasi pada Gambar 5, generasi sebanyak 10 menghasilkan rata-rata nilai fitness sebesar 24,41, kemudian mengalami peningkatan nilai fitness secara terus menerus hingga generasi sebanyak 40 dengan ratarata nilai fitness sebesar 50,10. Banyaknya generasi di atas 40 cenderung memberikan rata-rata nilai fitness yang stabil. Dengan demikian dapat diketahui bahwa banyaknya generasi yang optimal adalah generasi sebanyak 40.

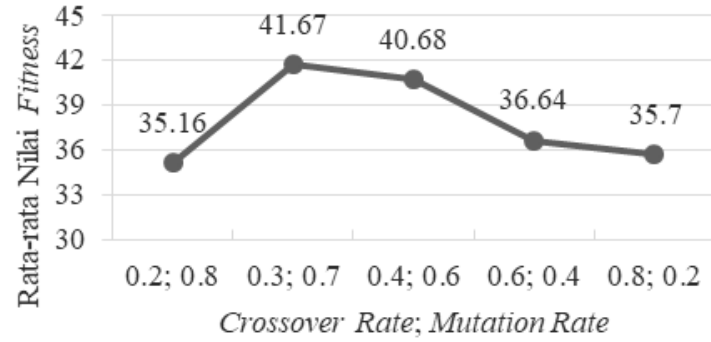

Gambar 6. Hasil pengujian crossover rate dan mutation rate

\section{Pengujian Crossover Rate dan Mutation Rate}

Pengujian crossover rate dan mutation rate dilakukan sebanyak 5 kali percobaan pada setiap skenario pengujian dengan rincian skenario kombinasi crossover rate ( $\mathrm{cr}$ ) dan mutation rate $(\mathrm{mr})$ yaitu 0,2 dan 0,8, 0,3 dan 0,7, 0,4 dan 0,6, 0,6 dan 0,4, serta 0,8 dan 0,2 . Pengujian dilakukan menggunakan ukuran populasi sebanyak 15 dan generasi sebanyak 40. Hasil pengujian crossover rate dan mutation rate ditunjukkan pada Gambar 6.

Berdasarkan grafik hasil pengujian crossover rate dan mutation rate pada Gambar 6, nilai cr dan mr sebesar 0,2 dan 0,8 menghasilkan rata-rata nilai fitness sebesar 35,16, kemudian mengalami peningkatan pada saat $\mathrm{cr}$ dan mr bernilai 0,3 dan 0,7 dengan rata-rata nilai fitness sebesar 41,67. Rata-rata nilai fitness cenderung mengalami penurunan pada saat nilai cr di atas 0,3. Dengan demikian dapat diketahui bahwa nilai cr dan mr yang optimal adalah 0,3 untuk nilai cr dan 0,7 untuk nilai mr.

Dengan menggunakan parameter-parameter optimal, algoritma genetika mampu membentuk komposisi menu makanan bagi penderita hipertensi dengan memperhitungkan kandungan zat gizi yang dibutuhkan oleh pasien tersebut. Algoritma genetika mampu memberikan hasil yang cukup baik tanpa melibatkan banyak persamaan seperti yang telah dilakukan oleh [5]. Selain itu, penggunaan metode extended intermediate crossover pada representasi kromosom integer menjadikan algoritma genetika mampu memberikan hasil yang baik dengan waktu komputasi yang kecil jika dibandingkan dengan [11]. Hal ini terlihat dari kecilnya nilai parameter algoritma genetika yang didapatkan dari seluruh hasil pengujian.

\section{KESIMPULAN}

Algoritma genetika dapat digunakan untuk menyelesaikan masalah optimasi komposisi makanan untuk penderita hipertensi. Representasi kromosom yang digunakan adalah representasi integer yang menggambarkan indeks dari jenis makanan. Kromosom terdiri dari 14 gen yang menunjukkan jenis makanan yang dikonsumsi dalam satu hari. Setelah melalui proses reproduksi dan seleksi, algoritma genetika menghasilkan sebuah solusi terbaik berupa komposisi 
makanan untuk penderita hipertensi makanan pokok, sumber nabati, sumber hewani, sayuran, dan makanan pelengkap. Untuk menghasilkan solusi yang optimal tersebut, parameter algoritma yang digunakan adalah ukuran populasi sebesar 15 , generasi sebanyak 40 , dan nilai cr dan mr sebesar 0,3 dan 0,7.

Pada penelitian selanjutnya, variasi makanan dapat ditambahkan untuk memperoleh keberagaman hasil penyusunan komposisi makanan bagi penderita hipertensi. Selain itu, pertimbangan mengenai penyakit lain yang mungkin diderita oleh seorang pasien hipertensi sehingga menyebabkan adanya pantangan terhadap makanan tertentu juga harus diperhitungkan.

\section{DAFTAR PUStaka}

[1] H. Nguyen, O. A. Odelola, J. Rangaswami, and A. Amanullah, "A Review of Nutritional Factors in Hypertension Management,” International Journal of Hypertension, vol. 2013, pp. 1-12, 2013.

[2] M. Ardiansyah, Medikal Bedah untuk Mahasiswa. Yogyakarta: Diva Press, 2012.

[3] M. Puspitorini, Hipertensi Cara Mudah Mengatasi Tekanan Darah Tinggi. Yogyakarta: Image Press, 2009.

[4] H. Okubo, S. Sasaki, K. Murakami, T. Yokoyama, N. Hirota, A. Notsu, M. Fukui, and C. Date, "Designing Optimal Food Intake Patterns to Achieve Nutritional Goals for Japanese Adults through the use of Linear Programming Optimization Models,” Nutrition Journal, vol. 14, no. 57, pp. 1-10, 2015.

[5] A. C. Iwuji, M. Nnanna, and N. I. C. Ndulue, “An Optimal DASH Diet Model for People with Hypertension Using Linear Programming Approach,” Open Journal of Optimization, vol. 5, no. 1, pp. 14-21, 2016.

[6] F. Zhang and W. B. Roush, "Multiple-objective (Goal) Programming Model for Feed Formulation: An Example For Reducing Nutrient Variation," Poultry Science, vol. 81, no. 2, pp. 182-192, 2002.

[7] M. A. Wolters, “A Greedy Algorithm for Unimodal Kernel Density Estimation by Data Sharpening," Journal of Statistical Software, vol. 47, no. 6, pp. 1-23, 2012.

[8] V. N. Wijayaningrum and F. Utaminingrum, "Numerical Methods for Initialization in Fodder Composition Optimization,” in 2016 International Conference on Advanced Computer Science and Information Systems (ICACSIS), Malang, Indonesia, Oct. 2016, pp. 397-400.
[9] V. N. Wijayaningrum, W. F. Mahmudy, and M. H. Natsir, "Optimization of Poultry Feed Composition Using Hybrid Adaptive Genetic Algorithm and Simulated Annealing,” Journal of Telecommunication, Electronic, and Computer Engineering, vol. 9, no. 2-8, pp. 183-187, 2017.

[10] F. Ramadhani, F. A. Fathurrachman, R. Fitriawanti, A. C. Rongre, and V. N. Wijayaningrum, "Optimasi Pendistribusian Barang Farmasi Menggunakan Algoritma Genetika,” Kumpulan Jurnal Ilmu Komputer (KLIK), vol. 5, no. 2, pp. 159-168, 2018.

[11] A. Kartikasari, D. E. Ratnawati, and T. S. Kusuma, “Optimasi Komposisi Makanan untuk Penderita Hipertensi Menggunakan Algoritma Genetika dan Simulated Annealing," Jurnal Pengembangan Teknologi Informasi dan Ilmu Komputer, vol. 1, no. 11, pp. 1236-1243, 2017.

[12] A. J. Umbarkar and P. D. Sheth, "Crossover Operators in Genetic Algorithms: A Review," ICTACT Journal on Soft Computing, vol. 6, no. 1, pp. 1083-1092, 2015.

[13] A. Hussain, Y. S. Muhammad, M. N. Sajid, I. Hussain, A. M. Shoukry, and S. Gani, "Genetic Algorithm for Traveling Salesman Problem with Modified Cycle Crossover Operator," Computational Intelligence and Neuroscience, vol. 2017, no. 1, pp. 1-7, 2017.

[14] B. Sutomo, Menu Sehat Penakluk Hipertensi. Jakarta: DeMedia Pustaka, 2009.

[15] W. Welis and M. S. Rifki, Gizi untuk Aktifitas Fisik dan Kebugaran. Padang: Sukabina Press, 2013.

[16] Cornelia, E. Sumedi, I. Anwar, R. Ramayulis, S. Iwaningsih, T. Kresnawan, and H. Nurlita, Konseling Gizi. Jakarta: Penebar Plus+, 2013.

[17] N. Devi, Nutrition and Food: Gizi untuk Keluarga. Jakarta: Kompas, 2010.

[18] M. Mehra, M. L. Jayalal, A. J. Arul, S. Rajeswari, K. K. Kuriakose, and S. A. V. S. Murty, "Study on Different Crossover Mechanisms of Genetic Algorithm for Test Interval Optimization for Nuclear Power Plants,” International Journal of Intelligent Systems and Applications, vol. 6, no. 1, pp. 20-28, 2014.

[19] M. Shafaat, I. Cholissodin, and E. Santoso, "Optimasi Komposisi Makanan Diet bagi Penderita Hipertensi menggunakan Algoritme Genetika,” Jurnal Pengembangan Teknologi Informasi dan Ilmu Komputer, vol. 2, no. 1, pp. 226-236, 2018. 